\title{
Strategi Branding Dalam Meningkatkan Kepercayaan Masyarakat Terhadap Madrasah Tsanawiyah Negeri
}

\author{
Karsono $^{1 *}$, Purwanto $^{2)}$, Abdul Matin Bin Salman ${ }^{3)}$ \\ 1,2,3Program Doktor Manajemen Pendidikan Islam, IAIN Surakarta \\ *Email korespondensi: karsono@gmail.com
}

This study aims to determine the branding strategy at MTsN Purbalingga Regency and to determine the level of effectiveness of branding management strategies at MTsN Purbalingga Regency in 2018 to 2020. This study uses a qualitative descriptive method. This method is used to describe and analyze branding management strategies at $M T s N$ in Purbalingga Regency and describe user responses to branding management strategies at MTsN Purbalingga Regency. The places chosen to conduct the research were MTsN 01 Purbalingga, MTsN 02 Purbalingga, and MTsN 03 Purbalingga. Informants from this research are principals, teachers, staff, and students. Then to select and determine the informants in this study, the researchers used a purposive sampling technique. Data collection techniques in this research are using content/document analysis techniques, in-depth interviews, and events/observations. The method used to check the validity of the data is the triangulation method. The data analysis technique used in this research is interactive model analysis. The stages in analyzing the data in this study are data reduction, data presentation, and conclusion drawing. The results showed that: 1). the branding strategies that have been carried out by MTsN in Purbalingga Regency between one MTsN and other $M T s N$ are the same and some are different, this of course depends on the branding management carried out by each school. MTsN 1 Purbalingga, namely by improving the quality both in terms of achievement and nonacademic namely character building, MTs Negeri 2 Purbalingga emphasizes efforts to attract interest in terms of performance and community service, while MTs Negeri 3 Purbalingga in an effort to attract interest by achieving good academic achievements and non-academic and performance services for both teachers and employees; 2). The effectiveness of the branding strategy carried out at MTs Negeri Purbalingga Regency in 2018 to 2020 is quite effective in increasing public trust.

Keywords: branding strategy, public trust, MTsN

Saran sitasi: Karsono., Purwanto., \& Salman, A. M. B. (2021). Strategi Branding Dalam Meningkatkan Kepercayaan Masyarakat Terhadap Madrasah Tsanawiyah Negeri. Jurnal Ilmiah Ekonomi Islam, 7(02), 869-880. doi: http://dx.doi.org/10.29040/jiei.v7i2.2649

DOI: http://dx.doi.org/10.29040/jiei.v7i2.2649

\section{PENDAHULUAN}

Pemasaran bagi lembaga pendidikan sangat diperlukan. Sebagai lembaga nonprofit yang bergerak dalam bidang jasa pendidikan, untuk level apa saja, maka diperlukan usaha untuk meyakinkan masyarakat dan pelanggan bahwa lembaga pendidikan yang dikelola masih tetap eksis. Selain itu, diperlukan usaha untuk menyakinkan bahwa layanan jasa pendidikan yang dikelola relevan dengan kebutuhan mereka. Kemudian, diperlukan kegiatan pemasaran agar jenis dan macam jasa pendidikan dapat dikenal dan dimengerti secara luas oleh masyarakat, apalagi "pelanggan". Pemasaran jasa pendidikan diperlukan agar eksistensi lembaga pendidikan yang dikelola tidak ditinggalkan oleh masyarakat luas serta "pelanggan" potensial (Wijaya, 2008).

Strategi pemasaran yang hendak dijadikan pijakan oleh lembaga pendidikan, tentu harus disesuaikan dengan perkembangan lingkungan. Tantangan lembaga pendidikan kedepan adalah adanya persaingan yang tinggi sehingga sangat banyak penawaran jasa lembaga pendidikan, meningkatnya tuntutan pelanggan atau siswa utamanya pada kualitas dan biaya, kemajuan teknologi komunikasi, informasi dan komputer (Fradito, 2016). Hal tersebut menjadi perhatian lembaga pendidikan 


\section{Jurnal Ilmiah Ekonomi Islam, 7(02), 2021, 870}

dengan memahami berbagai tantangan dan keterbatasan agar mampu mengembangkan dan mempertahankan eksistensi.

Berbagai strategi pemasaran dilakukan oleh instansi pendidikan negeri ataupun swasta. Persaingan antara pendidikan negeri dan swasta menjadi salah satu upaya lembaga pendidikan untuk terus melakukan strategi pemasaran. Melejitnya pendidikan swasta dalam menerapkan model branding untuk menarik minat siswa membuat pendidikan negeri menggencarkan strategi pemasaran untuk menarik kepercayaan masyarakat. Meskipun pendidikan negeri berada di bawah naungan pemerintah namun tetap membutuhkan strategi pemasaran yang baik. Tidak terkecuali pendidikan Islam negeri.

Pendidikan Islam di Indonesia secara tradisional dibedakan menjadi 2 sistem yaitu, sistem madrasah dan sistem pondok pesantren. Madrasah di bawah naungan Departemen Agama, selain memberikan pendidikan dan pengajaran agama juga memberi pelajaran umum. Sedangkan pesantren merupakan lembaga pendidikan Islam tradisional dengan ciri khas di dalamnya terdapat masjid, kiai, santri, dan pengajaran kitab kuning. Pendidikan Islam modern muncul dalam bentuk pendidikan Islam terpadu yang berada di bawah naungan Departemen Pendidikan dan Kebudayaan.

Melihat kondisi persaingan lembaga pendidikan saat ini, maka sudah seharusnya lembaga pendidikan Islam memiliki strategi pemasaran yang dapat dikolaborasikan dengan strategi bisnis yang mengacu pada peningkatan daya saing. Strategi daya saing ini dibutuhkan untuk menjaga eksistensi sebuah lembaga pendidikan, termasuk juga pada madrasah. Studi yang dilakukan (Cheng, Trivitt, \& Wolf, 2015) mengungkap bahwa sekolah agama membutuhkan strategi branding untuk mengkomunikasikan program distingtif sekolah yang membedakannya dengan sekolah sejenis. Sekolah agama cenderung menyesuaikan branding-nya dengan nilai agama yang menjadi arus utama dan mempunyai akar sejarah pada suatu daerah cenderung lebih dapat menarik siswa.

Branding bagi sekolah bukan sekadar menjual nama dan lokasi sekolah, melainkan juga menampilkan suatu identitas agar mudah dikenal dan mudah dibedakan dengan sekolah lainnya. Strategi branding sekolah menjadi sangat penting bagi sekolah-sekolah utamanya pada sekolah swasta. Sekolah perlu menampilkan proses pelayanan pendidikan melalui atribut kegiatan belajar mengajar yang unik, mutu pembelajaran, kepuasan belajar, prestasi siswa dan mutu lulusan. Sekolah perlu menampilkan kesan yang mendalam kepada siswa dan masyarakat tentang manfaat bersekolah di tempat tersebut (Sholihah, 2018).

Adapun untuk menentukan karakter yang ingin ditampilkan dalam strategi manajemen branding, sekolah dapat menggunakan 12 persona dasar (basic archetypes) yang umum dipakai dalam praktek branding atau pemasaran, yaitu mulai dari caregiver, creator, everyman, explorer, hero, innocent, jester, lover, magician, outlaw, ruler, dan sage. Karakteristik masing-masing basic archetypes pertama kali dicetuskan Carl Jung pada 1938 dan kemudian dikembangkan kembali oleh Mark dan Pearson pada 2001 hingga akhirnya banyak dijadikan pedoman dalam menentukan gambaran karakter suatu merek (Menkominfo, 2018). Secara ilmiah arketipe memberikan hubungan antara motivasi pelanggan dan penjualan produk. Pola dasar arketipe menandai pemenuhan keinginan dan motivasi dasar manusia. Archetypes adalah cerminan dari budaya di lingkungan setiap manusia. Beberapa karakter pada suatu merek terasa familiar bagi seseorang karena merupakan bagian dari alam bawah sadar. Teori ini merupakan bagian dari kepribadian merek, yang memiliki arti gabungan dari ketidaksadaran kolektif, kepribadian yang sangat tertanam, yang beresonansi dan berfungsi untuk mengatur serta memberikan arahan kepada pikiran dan tindakan manusia (Mark dan Pearson 2001).

Penelitian pasar dan akademis telah memberikan bukti bahwa merek yang menampilkan kepribadian/karakter yang kuat lebih cenderung berkinerja lebih baik dan beresonansi lebih lama dengan konsumen. Komponen kepribadian merek menggunakan hubungan antara merek kontemporer dan pola dasar arketipe klasik. Manajemen dapat memilih pola dasar arketipe yang paling sesuai untuk memperkuat branding sekolah (Roberts, 2010). Arketipe sebagai branding sekolah dapat mengungkapkan sebuah sekolah yang diminati publik cenderung kuat pada sisi kolegial, sisi kolegial yang efisien, atau manajerial (Bruckman and Carvalho, 2018).

Pola dasar arketipe memberikan gambaran bahwa sekolah yang di- branding dengan karakter yang kuat akan lebih mendapat tempat di benak masyarakat konsumen. Mundiri (2016) dalam penelitiannya menyatakan bahwa lembaga pendidikan 
yang tidak mampu memuaskan users educations sesuai dengan kebutuhan pasar, maka lembaga pendidikan tersebut tidak akan eksis dan bisa mengakibatkan lembaga pendidikan madrasah karena tidak mampu menjaring siswa baru dalam jumlah yang cukup, dan setiap tahun kecenderungannya mengalami penurunan jumlah siswa. Oleh karena itu madrasah harus berupaya semaksimal mungkin untuk mengelola serta meningkatkan kualitas layanannya sehingga apa yang dipromosikan bisa dipertanggungjawabkan. Karena pendekatan marketing menuntut mereka untuk menganalisis kegiatan belajar mengajar, intra dan ekstrakulikuler, fasilitas pendidikan, dan suasana belajar mengajar sehingga kegiatan mereka selalu terpusat pada perbaikan mutu pelayanan.

Penguatan karakter madrasah yang sesuai dengan pola dasar arketipe pada akhirnya menjadi inti dari strategi pemasaran lembaga pendidikan. Strategi pemasaran harus mampu menampilkan keunggulan karakter dan mutu lembaga pendidikan. Mundiri (2016) menyatakan aspek mutu dalam lembaga pendidikan Islam sangat memiliki keterkaitan erat dengan upaya membangun branding kelembagaan. Dalam hal ini, dimensi kualitas merujuk pada persepsi pelanggan mengenai kualitas atau keunggulan secara keseluruhan dari produk jasa pendidikan.

Beberapa kajian terdahulu telah membahas strategi manajemen dalam memperkuat branding terhadap sekolah/madrasah. Sholihah (2018) dalam penelitiannya menyimpulkan perencanaan strategi manajemen humas dirancang dan disusun dengan mempertimbangkan semua aspek hingga brand sekolah bisa sampai pada masyarakat. Implementasi dari strategi manajemen humas dilakukan humas sesuai jadwal yang telah di susun dengan melakukan promosi dan publikasi ke media cetak, media elektronik, dan sosial media, serta berkomunikasi dan sosialisasi ke publik secara langsung. Hasil dari strategi manajemen humas tersebut terlihat dengan adanya indikator keberhasilan sekolah menjadi terkenal di masyarakat, tercipta image positif bagi sekolah, peserta didik bertambah setiap tahun ajaran baru, menjadi sekolah favorit dan unggulan.

Robert (2010) menunjukkan bukti adanya tingkat persetujuan peserta yang tinggi saat mengkategorikan representasi pola dasar arketipe dari merek yang populer dan konsisten di seluruh kategori produk. Hasil penelitian ini juga mengimplikasikan perlunya untuk memahami bahwa ada beberapa tahapan dalam proses penguatan merek untuk dikaitkan dengan pola dasar arketipe. Polanya adalah merek dengan karakter terkuat adalah merek yang berpotensi mencapai status ikonik. Cheng, Trivitt, \& Wolf, (2015) menemukan bahwa orang tua dalam memilih sekolah dilakukan secara sistematis. Orang tua yang menghargai karakteristik sekolah tertentu cenderung memilih sekolah dengan merek yang mendukung karakteristik tersebut. Sekolah membawa merek yang mengomunikasikan informasi kepada orang tua yang kemudian menggunakan merek tersebut untuk membantu mereka memilih sekolah untuk anak-anak mereka.

Roziqin \& Rozaq (2018) menyatakan terdapat beberapa langkah yang dilakukan oleh lembaga madrasah dalam membentuk brand image, yaitu dengan melakukan akreditasi kelembagaan, menanamkan perilaku baik pada setiap siswa, meningkatkan prestasi siswa, meningkatkan kualitas guru dan kualitas lulusan, mengadakan kegiatan unggulan, serta menjalin hubungan dengan alumni. Langkah-langkah tersebut dapat meningkatkan daya saing.Adanya akreditasi sekolah, kualitas lulusan yang baik, prestasi siswa, dan perilaku siswa telah menarik perhatian masyarakat untuk memilih melanjutkan studi di madrasah. Rizkiyah, Istikomah, \& Nurdiyansyah, (2020) menyimpulkan strategi membangun sekolah branding diperlukan analisis tentang faktor-faktor apa saja yang menyebabkan sekolah kuat dalam branding, kemudian menyusun langkah-langkah dalam membangun branding, dan dampak atau manfaat sekolah branding terhadap daya saing.

Beberapa kajian telah mengungkap strategi manajemen dalam upaya penguatan branding sekolah, di antaranya adalah dengan penguatan mutu sekolah (Mundiri, 2016), penguatan karakter merek agar lebih kuat dalam pertimbangan konsumen (Roberts, 2010), penugasan humas untuk melakukan promosi dan publikasi tentang keunggulan sekolah ke berbagai media dan berkomunikasi serta sosialisasi langsung ke publik (Sholihah, 2018), branding dengan penguatan karakteristik sekolah (Cheng et al., 2015), membentuk brand image untuk meningkatkan daya saing sekolah (Roziqin \& Rozaq, 2018), serta membangun branding sekolah dengan melibatkan faktor-faktor penguat branding (Rizkiyah et al., 2020).

Seluruh kajian tersebut belum secara komprehensif mengungkap tentang upaya 
peningkatan branding madrasah melalui penguatan karakter-karakter dasar (arketipe) yang menjadi keunggulan madrasah. Diperlukan upaya pemilihan karakter dasar arketipe yang paling sesuai untuk kemudian dikomunikasikan sebagai keunggulan sekolah di madrasah. Urgensinya adalah untuk mengamati lebih jauh bagaimana upaya manajemen madrasah dalam mengelola beberapa karakteristik madrasah menjadi nilai unggul yang layak ditampilkan untuk penguatan branding madrasah, sehingga ke depannya madrasah menjadi pilihan masyarakat konsumen untuk menyekolahkan anaknya.

Kabupaten Purbalingga merupakan salah satu kabupaten di Propinsi Jawa Tengah secara administratif terbagi dalam 18 kecamatan, 224 desa dan 15 kelurahan. Berdasarkan jumlah data pendidikan (sekolah) di Kabupaten Purbalingga untuk sekolah menegah berjumlah 117 sekolah yang terdiri dari 63 sekolah negeri dan 54 sekolah swasta (https://.data.kemdikbud.go.id, 2020). Pada jenjang Madrasah terdapat 3 MTs Negeri dan 38 MTs Swasta sedangkan pada jenjang SMP terdapat 60 SMP negeri dan 16 SMP swasta. Berbagai sekolah tersebut tentunya senantiasa berupaya meningkatkan branding sekolah masing-masing melalui berbagai strategi pemasaran, dalam hal ini termasuk Madrasah Tsnawiyah Negeri (MTsN) yang ada di Kabupaten Purbalingga, hal tersebut dilakukan agar tidak ketinggalan dengan madrasah-madrasah swasta yang terus melakukan berbagai strategi pemasaran demi mendapatkan simpati dan kepercayaan dari masyarakat.

Berdasarkan latar belakang masalah di atas, penelitian ini akan mengkaji strategi pemasaran yang dilakukan oleh lembaga pendidikan Islam negeri, dalam hal ini ialah Madrasah Tsnawiyah Negeri (MTsN) di Kabupaten Purbalingga.

\section{Kajian Teori}

\subsection{Konsep Manajemen Brading}

Högström, Gustafsson, \& Tronvoll (2015) menjelaskan bahwa strategi manajemen branding yang dilakukan cenderung berbeda-beda tergantung pada cita- cita perusahaan.Apakah cita-cita perusahaan tersebut bermaksud menciptakan tipe nilai ekstrinsik atau intrinsik. Penciptaan nilai ekstrinsik berfokus pada utilitas dan funsionalitas yang ditawarkan kepada konsumen secara objektif sebagai sarana untuk mencapai tujuan lebih lanjut dalam kaitannya dengan harga dan apa yang dikorbankan. Penciptaan nilai intrinsik berfokus pada tanggapan subjektif yang dialami konsumen, yang dihargai karena pengalaman maupun bentuk simbolis ekspresi mereka, sehingga hal tersebut menjadi tujuan tersendiri.

Manajemen branding adalah sebuah pengelolaan yang bertujuan untuk membangun merek yang kuat, yaitu merek dengan ekuitas yang lebih tinggi.Membangun merek secara ekuitas membutuhkan investasi yang signifikan dari sumber daya perusahaan bersama dengan kemampuan yang diperlukan untuk menerapkan sumber daya tersebut secara efektif. Nampaknya terdapat sebuah kesepakatan bersama tanpa tertulis mengenai manajemen branding bahwa perusahaan industri memanfaatkan sumber daya keuangan ini terutama dalam tiga bidang, yaitu periklanan, penelitian \& pengembangan, dan manajemen hubungan pelanggan, yang telah terbukti secara positif mempengaruhi ekuitas merek (Rahman, Rodríguez-Serrano, \& Lambkin, 2018).

Definisi lain dijelaskan oleh (Heding, et al., 2009) yang mendefiniskan manajemen merek berfokus pada perusahaan di belakang merek dan tindakan yang akan diambil perusahaan untuk mempengaruhi konsumen. Dalam manajemen merek, konstruksi identitas telah tumbuh semakin populer, karena konsep yang kuat dan kompleks dengan potensi memperkuat daya kompetitif secara signifikan dan memastikan keselarasan identitas perusahaan, identitas organisasi, gambar, serta reputasi.Identitas merek mengekspresikan serangkaian nilai, kemampuan, dan proposisi penjualan dari sebuah merek.

\subsection{Konsep Brand, Branding, dan Citra}

Pengertian brand menurut (Sadat, 2009) diartikan sebagai istilah brand berasal dari kata brandr yang berarti "to brand", dimaknai sebagai aktivitas yang sering dilakukan para peternak sapi di Amerika untuk memberi tanda pada ternak-ternak mereka dengan tujuan agar mudah diindentifikasi kepemilikannya sebelum dijual ke pasar.

Beberapa pengertian mengenai hakikat brand dijelaskan oleh (Kapferer, 2008) pertama hakikat merek atau brand adalah aset tidak berwujud, aset yang menghasilkan manfaat tambahan bagi bisnis. Selain itu, merek diposting sebagai salah satu dari beberapa jenis aset tidak berwujud (kategori yang juga mencakup paten, database dan suka). Pengertian 
selanjutnya, merek adalah aset bersyarat, hal ini adalah titik kunci yang sejauh ini kerap diabaikan. Pengertian selanjutnya dari aset adalah elemen yang mampu menghasilkan manfaat dalam jangka waktu yang lama. Merek adalah nama yang mempengaruhi pembeli. Definisi ini menangkap esensi dari sebuah merek nama dengan kekuatan untuk mempengaruhi pembeli. Sedangkan menurut penuturan susanto, brand adalah nama atau simbol yang bersifat membedaka (seperti sebuah logo, cap atau kemasan) untuk mengidentifikasi barang atau jasa dari seorang penjual tertentu, serta membedakannya dari barang atau jasa yang dihasilkan para pesaing. Pada akhirnya, brand memberikan tanda mengenai sumber produk serta melindungi konsumen maupun produsen dari para pesaing yang berusaha memberikan produkproduk yang tampak identik dan lebih menarik (Susanto, 2012).

Berdasarkan penjelasan di atas, brand dimaknai sebagai simbol, identitas dan nama yang bersifat signifikan dalam sebuah produk. Sebuah brand memiliki kekuatan yang dapat mempengaruhi konsumen, oleh sebab diperlukan ketelitian dalam mengatur strategi manajemen branding itu sendiri.

Merek atau brand menempati tempat yang signifikan pada sebuah produk. Merek dijadikan sebagai identitas dalam mempromosikan sebuah produk agar mudah dikenal dan dihafal oleh khalayak. Pengertian merek menurut (Clifton, et al., 2003) adalah slogan, warna, jenis huruf tertentu. Tetapi namanya memiliki elemen terpenting dari merek karena penggunaannya dalam bahasa memberikan titik referensi universal. Namanya juga merupakan salah satu elemen dari merek yang seharusnya tidak pernah berubah. Definisi lain dijelaskan oleh (Kapferer, 2008) bahwa merek adalah sumber pengaruh; sistem asosiasi mental yang saling terhubung (brand image) dan hubungan. Pengertian merek atau brand dibagi menjadi dua kategori. Pertama, merek merupakan aset yang tidak berwujud, salah satu dari beberapa jenis aset tidak berwujud dikategorikan yang mencakup paten, database dan suka. Artinya, sebuah merek atau brand bukanlah suatu benda yang dapat disentuh atau dipegang, namun merek menjadi suatu hak paten yang telah ditetapkan oleh suatu lembaga atau organisasi. Kedua, merek adalah aset yang bersyarat. Hal ini adalah titik kunci dan sejauh ini justru diabaikan. Aset adalah elemen yang mampu menghasilkan manfaat dalam jangka waktu yang lama. Kendati demikian, aset bersyarat memberikan manfaat dan nilai finansial. Para pekerja atau orang-orang yang terlibat perlu melakukan kerja sama dengan aset material atau pendukung lainnya seperti fasilitas produksi, media promosi, dan orang-orang yang memiliki kompetisi tinggi untuk memajukan sebuah merek. Sebab dalam hal ini, tidak ada merek tanpa produk atau layanan untuk membawanya. Produk dan layanan menjadi efektif sebagai perwujudan dari sebuah merek, agar merek menjadi nyata dan dikenal.

Kemudian (Baeva, 2011) menambahkan bahwa merek dapat dilihat sebagai kombinasi dari produk yang dikeluarkan secara efektif, memiliki identitas yang khas dan memiliki nilai tambah. Merek yang kuat mewakili semua kualitas dan aspek nyata dan tidak berwujud dari suatu produk atau layanan. Selain itu, melalui merek, dapat mewakili segala perasaan dan persepsi tentang suatu kualitas, gambaran, gaya hidup, dan status. Dengan demikian, merek yang kuat akan mampu menciptakan persepsi dalam pikiran pelanggan bahwa tidak ada produk atau layanan lain di pasaran yang sama. Sehingga, lembaga pemilik merek akan mempertahankan nilai dimana konsumen dapat mengandalkan untuk konsisten dalam jangka waktu yang lama. Selanjutnya adalah (Kotler, et al., 2006) yang mendefinisikan merek adalah bentuk jaminan kualitas, asal, dan kinerja, sehingga meningkatkan risiko dan kompleksitas yang terlibat dalam suatu keputusan. Tujuan dari merek sendiri untuk memfasilitasi identifikasi produk, layanan, dan bisnis serta membedakannya dari kompetisi lain. Selain itu, macam-macam definisi merek disebutkan oleh (Heding, et al., 2009) diantaranya adalah brand extention, brand identity, brand Strategy. Ketiga merek tersebut berkaitan dengan pemertahanan pada sebuah lembaga utamanya sekolah.

Brand extention adalah merek yang digunakan untuk mendukung, mengembangkan, dan mempertahankan eksistensi sebuah merek dari perubahan lingkungan maupun memasuki pasar baru dengan tetap mempertahankan inti merek dan setia pada visi. Kemudian brand identity mengacu pada identitas merek dimana identitas tersebut harus menggambarkan visi, pekeunikan tertentu, dan kekhasan dari merek tersebut. Identitas merek harus bersifat permanen atau jangka panjang, dengan demikian dapat menciptakan dasar dari merek yang solid, koheren serta menjadi pendorong semua kegiatan terkait merek. Ketiga adalah brand strategy, tujuan dari strategi merek adalah meningkatkan 
peluang internal dan eksternal merek. Merek harus strategis, visioner dan proaktif daripada taktis dan reaktif. Setiap merek harus menemukan cawan sucinya sendiri untuk sukses dalam bentuk identitas merek dan visi merek yang unik dan relevan. Visi merek dihidupkan melalui strategi merek yang disesuaikan untuk merilis potensi penuh dari merek.

Selain itu, menurut Invalid source specified. ekuitas merek adalah konsep pemasaran yang penting. Signifikasi yang ada, bersumber dari branding yang kuat. Hal ini sejalan dengan Invalid source specified. yang menjelaskan bahwa branding yang kuat dimulai dari analisis diri dan tujuan yang cerdik menurut identitas, branding mengekspresikan identitas melalui barang, pelayanan, lingkungan dan perilaku di berbagai platform di dalam berbagai konteks. Ia juga menambahkan bhawa branding yang bagus adalah konsistensi citra dan identitas di berbagai platform dengan cara yang menarik, bermakna, dan loyalitas untuk membangun dengan basis pelanggan yang ditargetkan dan dispesifikkan.

Simpulan dari beberapa pendapat ahli di atas, merek atau branding adalah sesuatu yang khas, yang dijadikan identitas suatu lembaga sebagai pengenal agar mudah dikenali oleh masyarakat. Mengemas sebuah merek tentunya memerlukan strategi dan manajemen yang dalam agar akhir yang diharapkan memberikan dampak pada merek untuk dikenal banyak orang. Oleh sebab itu, merek merupakan aset penting dari sebuah lembaga yang perlu dan harus dijaga sampai nanti.

Pendapat Kotler (2002) menjelaskan mengenai image bermula terbentuk dari bagaimana sebuah lembaga melaksanakan kegiatan operasional yang mempunyai landasan utama pada segi layanan. Selain itu, image juga terbentuk berdasarkan impresi dan pengalaman yang dialami seseorang terhadap sesuatu, sehingga membangun suatu sikap mental. Ia mengaskan bahwa image yang memiliki nilai positif akan lebih memungkinkan menarik konsumen untuk melakukan transaksi pembelian. Sebab brand yang baik akan menjadi dasar untuk membangun citra lembaga yang positif. Sedangkan Menurut (Levitt, 1983) menambahkan mengenai pengertian image adalah kesan, perasaan, apresiasi dari masyarakat atau publik terhadap perusahaan atau organisasi, yang dibuat secara bersyarat dari objek, orang, atau organisasi dalam suatu lembaga. Konsep image atau citra diperoleh melalui pengetahuan, pemahaman, dan pengalaman seseorang mengenai sesuatu. Selain itu, pendapat lain dijelaskan oleh (Wibowo, 2018) mengenai image positif dimata publik atau masyarakat menjadi baik apabila mengandung kredibilitas dalam suatu organisasi. Kredibel tersebut mencakup dua hal, pertama harapan, kemampuan memenuhi kebutuhan maupun kepentingan publik dan kepercayaan untuk tetap komitmen dalam menjaga kepentingan, dan kenyamanan bersama untuk mewujudkan investasi sosial, melalui program-program yang ditujukan untuk kesejahteraan sosial.

Sintesis mengenai penjelasan di atas bahwa citra dimaknai sebagai suatu ide, kesan, konsep perasaan yang didapat melalui panca indera maupun berbagai sumber tertentu. Citra yang baik akan menghasilkan respon yang baik, dalam pandangan masyarakat terhadap suatu organisasi, orang, maupun lembaga.

Kebijaka branding tertulis pada beberapa undang-undang yang diatur oleh AMA (American Marketing Association). Definisi brand menurut AMA (American Marketing Association) menjadi acuan dalam pendefinisan brand atau merek dalam Undang-Undang Merek No.15 tahun 2001 pasal 1 ayat 1: yakni "tanda yang berupa gambar, nama, kata, huruf-huruf, angka-angka, susunan warna,atau kombinasi dari unsur-unsur tersebut yang memiliki daya pembeda dan digunakan dalam kegiatan perdagangan barang atau jasa" (UU Merek, 2001). Selain itu, perihal regulasi, hak merek di Indonesia ditetapkan berdasarkan prinsip "first to file" atau "stelsel konstitutif" dan bukan atas dasar "first to use" atau "stelsel deklaratif" yang secara historis pernah diberlakukan di Indonesia dalam UU No.21 tahun 1961. Kebijakan yang diberikan First to use berlaku untuk siapa saja yang memberikan kebijakan kepada siapa saja yang mendaftarkan brand atau merek tersebut pertama kali di negara tersebut, kendati brand itu sebelumnya diketahui digunakan oleh instansi badan atau orang lainnya. Selagi belum terlegalisasi, badan atau orang yang mendaftarkannya pertama kali akan memiliki hak terhadap brand tersebut. Kemudian, (Tjiptpno, 2012) menambahkan kebijakan undang-undang mengenai brand, yang pada saat ini telah dilakukan tiga kali penggantian UU diantaranya adalah (UU No.19 Tahun 1992, UU No.14 Tahun 1997, terakhir di amandemen dengan dikeluarkannya UU No.15 Tahun 2001 prinsip hak merek menggunakan "stensel konstitutif”, 15 Pada rangkaian Undang Undang yang dijadikan acuan tersebut, proteksi khusus diberikan bagi merek terkenal asing dan Indonesia. Lebih lanjut 


\section{Jurnal Ilmiah Ekonomi Islam, 7(02), 2021, 875}

pasal 6 ayat 2 menetapkan bahwa ketentuan yang diberikan berlaku sebagaimana dimaksud pada ayat $1 \mathrm{~b}$ tersebut dapat pula diberlakukan terhadap barang dan jasa yang tidak sejenis sepanjang memenuhi persyaratan tertentu yang akan ditetapkan lebih lanjut dengan peraturan pemerintah. Hal ini berlaku meskipun registrasi brand atau merek bersifat sukarela di Indonesia (berbeda dengan pendaftaran perusahaan yang bersifat wajib). Beberapa tahun terakhir kesadaran dan minat pemilik merek untuk mendapatkan perlindungan hukum atas merek-merek yang dimilikinya mengalami peningkatan.

\subsection{Komponen Branding}

Pemilihan branding, tentu memiliki beberapa elemen atau komponen sebagai suatu identitas dari brand itu sendiri, diantaranya adalah emelen tangible (nyata) dan intangible (tidak nyata).

Menurut Oktaviani, dkk, (2018) menjelaskan mengenai fungsi branding, salah satunya adalah sebagai sarana untuk menanamkan citra positif di benak konsumen dan pengamat. Sehingga dalam hal ini, para pelaku lembaga pendidikan perlu memperhatikan citra madrasah, sebab branding adalah produk yang penting sebagai poin agar produk dan kualitas sekolah senantiasa diingat, dipercaya, dan dipilih oleh konsumen atau masyarakat dalam jangka waktu yang lama. Selain itu, Nastain (2017) menyatakan fungsi brand sebagai satu ikatan yang memiliki kekuatan secara emosional antara pemilik dan konsumen, tataran tersebut terbagi menjadi beberapa opsi secara strategis dan kekuatan yang mempengaruhi finansial. Kekuatan dan loyalitas dari pelanggan, mampu mengikat brand untuk mengantarkan keberhasilan dalam berbisnis, ketangguhan dan produk yang mampu bersaing. Adapun fungsi brand dengan keberagaman dan jenisnya yang bermacam-macam, tentunya memiliki tujuan dan fungsi yang berbeda-beda.

Penjelasan di atas merupakan fungsi branding branding sebagai salah satu sarana untuk menanamkan citra positif di benak konsumen, dengan memberikan kesan emosional yang baik antara pelaku dan konsumen. Dalam hal ini, kaitannya dengan lembaga pendidikan, fungsi brand bertujuan untuk memasarkan, menggait, dan memasarkan brand madrasah agar mampu bersaing baik dalam hal mutu, kepercayaan dan layanan pendidikan yang unggul dimata masyarakat.

Menurut Keller dalam (Tjiptono, 2005) membagi manfaat pokok merek menjadi tujuh bagian, diantaranya adalah sumber produk diidentifikasi, pemanufakturan atau distributor sebagai penetapan tanggung jawab, pengurang risiko, (search costs) atau penekanan biaya pencarian untuk internal dan eksternal, ikatan khusus atau janji dengan produsen, simbolis sebagai alat untuk memproyeksi citra diri, dan kualitas signal.

\subsection{Brand pada Lembaga Pendidikan}

Spesifikasi dari manfaat branding, dapat ditarik dalam ranah dunia pendidikan, Menurut (Sadat, 2009) merek atau brand yang dihasilkan dapat memberikan kekuatan dan jaminan nilai yang berkualitas tinggi terhadap stakeholders. Hal tersebut yang pada akhirnya berdampak luas terhadap institusi pendidikan. Sadat membagi manfaat brand yang dapat diperoleh dari stakeholders dan lembaga pendidikan, berikut manfaatnya:

Implikasi branding tidak hanya terbatas pada produk atau perusahaan. Sekolah memiliki implikasi brandingnya tersendiri. Jika dilihat dari perspektif corporate, maka lembaga pendidikan merupakan suatu organisasi yang memproduksi jasa pendidikan yang dibeli oleh konsumen. Apabila produsen dalam hal ini lembaga pendidikan tidak dapat memasarkan hasil produksinya, yaitu jasa pendidikan, yang disebabkan oleh mutu yang tidak mencapai tingkat kepuasan konsumen, maka produk yang ditawarkan tidak laku. Jika lembaga pendidikan tidak mampu memenuhi kebutuhan pasar, maka eksistensinya terancam menghilang. Berbeda dengan produk berbentuk fisik, produk sekolah yang berbentuk layanan tidak dapat disimpan, sebagai hasilnya layanan tersebut diproduksi dan dikonsumsi secara bersama (Dwiyama, 2019).

Produk lembaga pendidikan yang tidak berwujud, konsumen pada umumnya dapat mengenali tanda-tanda yang digunakan utnuk menilai kualitas produk lembaga pendidikan. Penilaian itu dapat diketahui dari performa guru, tenaga pendidikan, sarana prasarana sekolah serta manajemen sekolah yang ada pada suatu lembaga pendidikan. Berdasarkan hal ini, lembaga pendidikan perlu menyadari pentingnya membangun branding yang kuat untuk mendapatkan kepercayaan konsumen dan mempertahankan eksistensinya. Karena branding yang diutamakan dalam dunia pendidikan adalah branding yang kuat sehingga memberikan jaminan akan kualitas dan nilai yang memuaskan kepada stakeholder, yang kemudian berdampak luas pada lembaga pendidikan (Sadat, 2009). 


\section{Jurnal Ilmiah Ekonomi Islam, 7(02), 2021, 876}

\subsection{Konsep Strategi Manajemen Branding}

Kemajuan suatu lembaga maupun suatu organisasi dapat dilihat dari strategi yang dirancang dengan baik. Kesukesan dalam pengimplementasian suatu strategi dipengaruhi oleh kekuatan identifikasi masalah mengenai apa, bagaimana, mengapa dan dimana kepemimpinan dan tekad harus diterapkan secara fokus. Pengertian strategi dijelaskan oleh (Kamal, dkk, 2020) bahwa strategi adalah rencana tindakan yang dirancang untuk mencapai tujuan jangka panjang dalam berbisnis. Kemudian Rumelt (2011) menjelaskan bahwa strategi yang baik cakupannya adalah serangkaian tindakan yang koheren. Artinya, keuntungan alami pertama dari strategi yang baik muncul karena organisasi lain sering tidak memilikinya. Strategi yang baik memiliki koherensi, tindakan koordinasi, kebijakan, dan sumber daya sehingga mencapai akhir yang penting.

Schein (2008) memberi definisi manajemen sebagai profesi. Hal ini menegaskan bahwa manajemen merupakan suatu profesi yang dituntut untuk bekerja secara profesional. Karakteristik profesional ini diwujudkan dalam bentuk membuat keputusan berdasarkan prinsip-prinsip umum. Sikap profesional diperoleh dari pencapaian standar prestasi kerja tertentu dan ditentukan oleh kode etik yang kuat. Kemudian, definisi lain dijelaskan oleh (Drummond, et al., 2008) bahwa manajemen dapat menyediakan alat umum dan teknik analitis memungkinkan penilaian dan kontrol masalah, situasi, dan area fungsional. Tujuannya adalah untuk memberikan reaksi dan pengaruh, lingkungan kompetitif untuk keuntungan organisasi. Selanjutnya, (Nashar, 2013) menambahkan pengertian manajemen adalah sebuah proses pengelolaan atau kerangka kerja yang melibatkan bimbingan dan pengarahan kepada orang lain atau suatu kelompok ke arah tujuan organisasional atau maksud-maksud yang diperlukan. Manajemen adalah kegiatan, dimana pelaksanaanya adalah "managing" pengelolaan, sedangkan pelaksananya disebut manager atau pengelola.

Layanan merupakan persoalan yang serius bagi para manajer, termasuk manajer pendidikan Islam.Ini terutama ketika mereka menghendaki peningkatan di segala bidang sebagai modal dasar dalam memajukan lembaga pendidikan yang dikendalikannya. Terlebih lagi bagi manajer yang merencanakan lembaganya bisa mengungguli lembaga lain tentu pelayanan menjadi salah satu komponen pengelolaan pendidikan yang harus mendapat perhatian khusus (Qomar, 2007).
Falsafah yang harus diimplementasikan oleh manajer lembaga pendidikan Islam adalah falsafah penjual.Sebagai penjual yang baik ada sikap-sikap tertentu yang ditampilkan keada para pembeli, antara lain; (1) Berusaha memberikan pelayanan dengan cepat dan tepat, berusaha bersikap ramah, (3) Berusaha mematok harga yang bersaing, (4) Berusaha mengibur pembeli, (5) Berusaha bersikap jujur, dan (6) Berusaha mampu menahan diri dari perasaan kecewa jika ada pembeli yang bersikap kurang menyenangkan (Qomar, 2007).

Oleh karena itu paradigma yang perlu dijadikan pegangan bagi para menajer lembaga pendidikan Islam, baik kapasitasnya sebagai kepala madrasah, pengasuh/kiyai pesantren, ketua jurusan, dekan, maupun rektor adalah sebagai pelayan umat. Hal tersebut berarti bahwa mereka harus memberikan pelayanan yang terbaik kepada orang lain baik jajaran pimpinan, para guru, siswa, para karyawan, para wali murid, para pengguna lulusan dan masyarakat luas. Madrasah atau lembaga pendidika Islam dikatakan berhasil apabila mamapu memberikan layanan yang sama atau melebihi harapan pelanggan. Dengan demikian manajemen layanan sangat perlu diperhatikan oleh lembaga pendidikan Islam, karena akan dapat meningkatkan kepercayaan masyarakat terhadap madrasah, sehingga dengan peningkatan kepercayaan tersebut akan dapat meningkatkan mutu pendidikan lembaga.

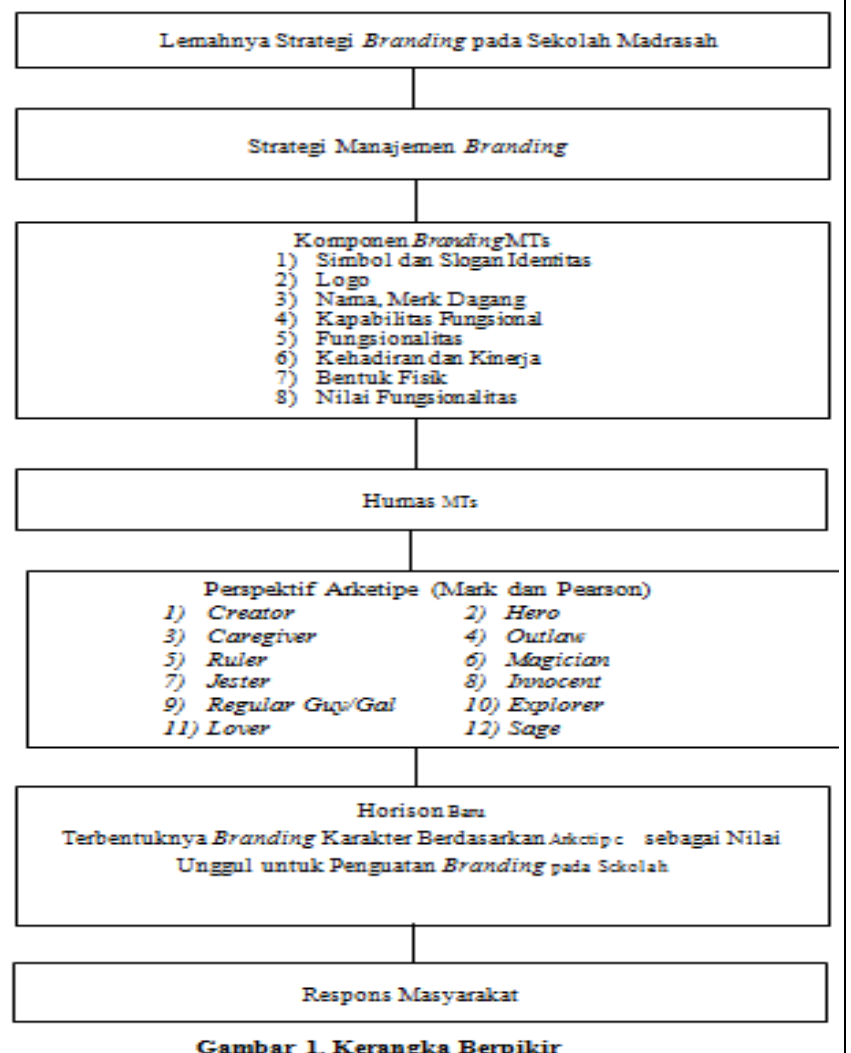

Gambar 1. Keranglka Berpikir 


\section{METODOLOGI PENELITIAN}

Penelitian ini menggunakan metode deskriptif kualitatif. Kualitatif adalah penelitian yang dapat dideskripsikan dalam bentuk kata-kata, dan bahasa pada konteks alamiah dan dengan memanfaatkan metode yang alamiah(Moleong, 2013). Penelitian kualitatif bertujuan untuk memperoleh wawasan terkait konstruksi realitas yang terjadi untuk ditafsirkan (Cropley, 2019). Metode tersebut digunakan untuk mendeskripsikan dan menganalisis strategi manajemen branding di MTsN di Kabupaten Purbalingga dan mendeskripsiskan respons pengguna terhadap strategi manajemen branding di MTsN Kabupaten Purbalingga pada tahun 2018 sampai dengan 2020. Tempat yang dipilih untuk melakukan penelitian yaitu di MTsN 01 Purbalingga, MTsN 02 Purbalingga, dan MTsN 03 Purbalingga. Informan dari penilitian ini adalah kepala sekolah, guru, staff, dan siswa. Untuk memilih dan menentukan informan dalam penelitian ini, peneliti menggunakan teknik purpossive sampling.

Teknik pengumpulan data dalam penelitian ini ialah dengan menggunakan teknik analisis isi/dokumen, wawancara mendalam (in depth interview), dan peristiwa/observasi. Metode yang digunakan untuk memeriksa keabsahan data adalah dengan triangulasi method yaitu dengan memanfaatkan berbagai metode sebagai pertimbangan. Triangulasi ini dilakukan dengan jalan membandingkan dan mengecek informasi atau data yang diperoleh dari dokumentasi dengan hasil pengamatan dan interview (Moleong, 2014). Triangulasi ini dilakukan dengan; (1) membandingkan data hasil pengamatan dengan data hasil wawancara, (2) membandingkan apa yang dikatakan orang di depan umum dengan yang dikatakan pribadi, (3) membandingkan apa yang dikatakan orang tentang situasi penelitian dengan apa yang didapat selama penelitian, (4) membandingkan keadaan dan perspektif seseorang dengan berbagai pendapat dan pandangan yang lain, dan (5) membandingkan hasil wawancara dengan isi suatu dokumen yang berkaitan. Teknik analisis data yang digunakan dalam penelitian ini adalah analisis model interaktif (Miles \& Huberman, 1992). Tahap-tahap dalam menganalisis data pada penelitian ini ialah reduksi data, penyajian data, penarikan kesimpulan.

\section{HASIL PENELITIAN}

4.1. Strategi branding yang telah dilakukan MTsN di Kabupaten Purbalingga

Strategi branding yang telah dilakukan MTsN di Kabupaten Purbalingga antara MTsN yang satu dengan MTsN yang lainnya tentu ada yang sama dan tentu pula ada yang berbeda, hal itu tentunya tergantung manajemen branding yang dilakukan dari masing-masing sekolah, terutama sebagai pengambil keputusannya yaitu masing-masing kepala sekolah mereka sebagai top manajemen.

a. Strategi baranding di MTsN 1 Purbalingga

Hasil wawancara dengan Kepala MTs Negeri 1 Purbalingga Ibu Siti Mudrikah, beliau menyampaikan bahwa MTsN 1 Purbalingga sudah mempunyai brand tersendiri di masyarakat. Strategi yang digunakan yang utama tentunya terus meningkatkan kualitas baik dari segi prestasi maupun ahlak sehingga ada semacam diferensiasi output madrasah dan sekolah umum. Selain itu lulusan MTs N 1 Purbalingga dapat melanjutkan kejejang SMA/MA bergengsi. Secara teratur MTs $\mathrm{N} 1$ Purbalingga mengunggah aktivitas melalui media baik cetak maupun online seperti majalah Gema Matsabangga, Suara Merdeka, Tabloid Aspirasi, Tabloid Elemen, Facebook, Instagram, YouTube, Website Kanwil Kemenag dan lainya (Wawancara tanggal 08 Maret 2021). Berdasarkan hasil wawancara pula baik dengan kepala sekolah, guru, staf, dan siswa bahwa upaya dalam menarik minat dari masyarakat di MTs N 1 Purbalingga yaitu dengan cara meningkatkan kualitas baik dari segi prestasi maupun non akademik yaitu penanaman karakter supaya masyarakat bisa membedakan antara lulusan madrasah dan lulusan sekolah. Siswa MTs N 1 Purbalingga juga di didik untuk memberi kemanfaatan bagi masyarakat di lingkungannya seperti menjadi muadzin, qori, dan lainnya. Keadaan yang demikian inilah, yang menjadikan kepercayaan masyarakat terhadap MTs N 1 Purbalingga terus terjaga dan bahkan cenderung mengalami peningkatan, dengan kata lain MTs N 1 Purbalingga merupakan MTsN yang menjadi salah satu madrasah tsanawiyah rujukan utama bagi masyarakat sekitar dalam menyekolahkan putra putri mereka yang didasarkan pada kualitas yang telah dibuktikannya terutama kualitas lulusannya. 
b. Strategi baranding di MTsN 2 Purbalingga

Hasil wawancara dengan Kepala MTs Negeri 2 Purbalingga bapak Sangidurohman, menyatakan bahwa strategi yang digunakan untuk meningkatkan branding Madarsah adalah dengan melaksanakan Try out MI/SD dari hasil/nilai rengking 1.2.3 langsung diterima, menerapkan kedisiplinan semua civitas Madrasah (Guru, pegawai dan siswa) dan Lulus Madrsah hafal Asmaul khusna, hafal jus 30 dan doa-doa harian (Wawancara tanggal 08 Maret 2021). Berdasarkan hasil wawancara pula baik dengan kepala sekolah, guru, staf, dan siswa bahwa upaya dalam menarik minat dari masyarakat di MTs N 2 Purbalingga yaitu MTs Negeri 2 Purbalingga menekankan upaya menarik minat dari sisi kinerja dan pelayanan masyarakat. Kinerja tersebut tentunya bermuara pada peningkatan prestasi yang ada di MTs Negeri 2 Purbalingga, baik prestasi dari pada pengelola/manajemen madrasahnya maupun prestasi dari para peserta didik. MTs Negeri 2 Purbalingga juga senantiasa berkomunikasi dengan masyarakat secara intens terutama dengan masyarakat di sekitar madrasah dan para tokoh masyarakat serta siap memberikan pelayanan masyarakat yang dibutuhkan selama memberikan kemanfaatan yang berarti sesuai dengan tujuan madrasah yang telah dicanangkan baik jangka pendek maupun jangka panjang.

c. Strategi baranding di MTsN 3 Purbalingga

Hasil wawancara dengan bapak Sudir selaku kepala Madrasah di MTs Negeri 3 Purbalingga bahwa strategi branding yang dilaksanakan baru sekedar mempublikasikan prestasi via Sosmed dan website (berupa youtube, IG, FB, dan status WA masing-masing guru)." (Wawancara tanggal 08 Maret 2021). Berdasarkan hasil wawancara pula baik dengan kepala sekolah, guru, staf, dan siswa bahwa upaya dalam menarik minat dari masyarakat di MTs N 3 Purbalingga yaitu MTs Negeri 3 Purbalingga dalam upaya menarik minat dengan cara meraih prestasi baik akademik dan non akademik serta pelayanan kinerja baik guru dan pegawai.

4.2. Tingkat efektivitas strategi manajemen branding di MTsN Kabupaten Purbalingga

Berbicara tentang efektivitas strategi branding yang dilakukan di MTs Negeri Kabupaten Purbalingga pada tahun 2018 sampai dengan 2020, dapat dilihat dari perkembangan jumlah siswa dari tahun ke tahun tersebut sebagai indikator pula terhadap besar kecilnya kepercayaan masyarakat terhadap Madrasah Tsanawiyah Negeri di Kabupaten Purbalingga. Di bawah ini merupakan tabel yang menunjukkan perkembangan jumlah siswa di Madrasah Tsanawiyah Negeri Kabupaten Purbalingga selama tahun 2018-2020 MTsN 1 Purbalingga, MTsN 2 Purbalingga, dan MTsN 3 Purbalingga.

Tabel 1

Jumlah Siswa di MTsN Kabupaten Purbalingga Tahun 2018-2020

\begin{tabular}{|c|c|c|c|c|}
\hline No & Nama Madrasah & \multicolumn{3}{|c|}{$\begin{array}{c}\text { Jumlah Siswa } \\
\text { Pada Tahun }\end{array}$} \\
\cline { 3 - 5 } & & $\mathbf{2 0 1 8}$ & $\mathbf{2 0 1 9}$ & $\mathbf{2 0 2 0}$ \\
\hline 1. & MTs Negeri 1 Purbalingga & 830 & 866 & 883 \\
\hline 2. & MTs Negeri 2 Purbalingga & 815 & 571 & 881 \\
\hline 3. & MTs Negeri 3 Purbalingga & 105 & 210 & 313 \\
\hline
\end{tabular}

Sumber: http://emispendis.kemenag.go.id/

Berdasarkan data pada tabel 1 di atas, jumlah siswa tersebut dapat diketahui bahwa terjadinya peningkatan jumlah siswa pada setiap tahunnya (kecuali MTsN 2 Purbalingga dari 2018 ke 2019) menunjukkan adanya kepercayaan masyarakat untuk menyekolahkan anaknya di Madrasah Negeri di Kabupaten Purbalingga. Hal tersebut dapat diartikan madrasah melakukan manajemen branding terhadap madrasahnya agar tetap selalu mendapatkan dukungan. Dilihat dari jumlah siswa yang masuk ke MTs Negeri 1 dan MTs Negeri 2 lebih banyak dibandingkan dengan MTs Negeri 3. Hal tersebut disebabkan MTs Negeri 3 merupakan Madrasah yang belum lama berdiri di Kabupaten Purbalingga yaitu baru 2 (dua) tahun berjalan. Sedangkan dilihat dari sisi branding pada ke dua MTs yaitu MTs Negeri 1 dan MTs Negeri 2 terlihat dari jumlah siswa yang terpaut tidak terlalu banyak. Dengan data tersebut pula dapat ditarik suatu kesimpulan bahwasanya efektivitas strategi branding yang dilakukan di MTs Negeri Kabupaten Purbalingga pada tahun 2018 sampai dengan 2020 cukup efektif dalam meningkatkan kepercayaan masyarakat.

\section{KESIMPULAN}

Berdasarkan hasil penelitian, maka dapat disimpulkan bahwa: 1). strategi branding yang telah dilakukan MTsN di Kabupaten Purbalingga antara MTsN yang satu dengan MTsN yang lainnya ada yang sama dan ada pula yang berbeda, hal itu tentunya tergantung manajemen branding yang dilakukan dari 
masing-masing sekolah. MTs N 1 Purbalingga yaitu dengan cara meningkatkan kualitas baik dari segi prestasi maupun non akademik yaitu penanaman karakter, MTs Negeri 2 Purbalingga menekankan upaya menarik minat dari sisi kinerja dan pelayanan masyarakat, sedangkan MTs Negeri 3 Purbalingga dalam upaya menarik minat dengan cara meraih prestasi baik akademik dan non akademik serta pelayanan kinerja baik guru dan pegawai; 2). efektivitas strategi branding yang dilakukan di MTs Negeri Kabupaten Purbalingga pada tahun 2018 sampai dengan 2020 cukup efektif dalam meningkatkan kepercayaan masyarakat.

\section{DAFTAR PUSTAKA}

Baeva, D. Y. (2011). Strong Brands How Brand Strategy and Brand Communication Contribute to Build Brand Equity. Universidade De Coimbra.

Bruckmann, S., \& Carvalho, T. (2018). Understanding change in higher education: An archetypal approach. Higher Education, 76(4), 629-647.

Cheng, A., Trivitt, J., \& Wolf, P. J. (2015). School Choice and the Branding of Milwaukee Private Schools. Journal of EDRE Working Paper, (04).

Clifton, R., Simmons, J., \& et, a. (2003). Brands and Branding. London: Profile Book. Cropley, A. (2019). Introduction to Qualitative Research Methods. Riga, Latvia: Zinātne. https://doi.org/10.13140/RG.2.1.3095.6888

Drummond, G., Ensor, J., \& Ashford, R. (2008). Strategic Marketing Planing and Control. New York: Elsevier.

Dwiyama, F. (2019). Brand Image: Upaya Memasarkan Pendidikan Bagi Lembaga Yang Kurang Mampu Bersaing. Adaara: Jurnal Manajemen Pendidikan Islam, 9(2), 880-891. https://doi.org/10.35673/ajmpi.v9i2.424

Fradito, A. (2016). Strategi pemasaran pendidikan dalam meningkatkan citra Lembaga Pendidikan Islam: Studi Multikasus di SDI Surya Buana dan MIN Malang 2 (Doctoral dissertation, Universitas Islam Negeri Maulana Malik Ibrahim).

Heding, T., Knutdzen, C. F., \& Bjerre, M. (2009). Brand Management Research, theory and practice. New York: Routledge.
Högström, C., Gustafsson, A., \& Tronvoll, B. (2015). Strategic Brand Management: Archetypes for Managing Brands Through Paradoxes .Journal of Business Research, 68(2), 391-404. https://doi.org/10.1016/j.jbusres.2014.06.009

Kotler P. (2002). Manajemen Pemasaran Edisi Milenium. Jakarta : PT. Prehellindo.

Kotler, P., \& Pfoertsch, W. (2006). B2B Brand Management with the Cooperation of Ines Michi. New York : Springer Berlin.

Lahir, S., Ma'ruf, M. H., \& Tho'in, M. (2017). Peningkatan Prestasi Belajar Melalui Model Pembelajaran Yang Tepat Pada Sekolah Dasar Sampai Perguruan Tinggi. Jurnal Ilmiah Edunomika, 1(01).

Levitt. 1983. The Marketing Imagenation. London: The Free Press.

Mark, M., \& Pearson, C. S. (2001). The Hero and The Outlaw: Building Extraordinary Brands Through the Power of Archetypes. New York: McGraw-Hill.

https://doi.org/10.1036/007138118X

Miles, M. B., \& Huberman, A. M. (1992). Analisis

Data Kualitatif. (T. R. Rohidi, Ed.). Jakarta: UIPress.

Moleong, Lexy J. (2013). Metodologi Penelitian Kualitatif. Bandung: Remaja Rosdakarya. Mulyasa, E. 2003. Menjadi Kepala Sekolah Profesional dalam Konteks Menyukseskan MBS dan KBK. Bandung: PT Remaja Rosdakarya

Mundiri, A. (2016). Strategi Lembaga Pendidikan Islam Dalam Membangun Branding Image. Jurnal Pendidikan Pedagogik, 3(2).

Nashar. (2013). Dasar-dasar Manajemen. Pamekasan: STAIN Pamekasan.

Nastain, Muhamad. (2017). Branding Dan Eksistensi Produk (Kajian Teoritik Konsep Branding Dan Tantangan Eksistensi Produk). Channel. 5, (1), 14-26.

Oktaviani, Femi. Dkk. (2018) Penguatan Produk UMKM "Calief" Melalui Strategi Branding Komunikasi. Jurnal Pengabdian Kepada Masyarakat. 1 (2), 348-354.

Qomar, M. (2007). Manajemen Pendidikan Islam. Malang: Erlangga. 
Rahman, M., Rodríguez-Serrano, M. Á., \& Lambkin, M. (2018). Brand Management Efficiency and Firm Value: An Integrated Resource Based and Signalling Theory Perspective .Industrial Marketing Management, 72(July 2017), 112126.

Rizkiyah, R., Istikomah, I., \& Nurdiyansyah, N. (2020). Strategies to Build a Branding School in Efforts to Improve the Competitiveness of Islamic Education Institutions: In Strategi Membangun Branding School dalam Upaya Meningkatkan Daya Saing Lembaga Pendidik.

Roberts, C. (2010). Exploring Brand Personality through Archetypes. East Tennessee State University.

Roziqin, Z., \& Rozaq, H. (2018). Menggagas Competitive Advantage Melalui Branding Image Di Madrasah Aliyah Nurul Jadid Paiton Probolinggo. Jurnal Ilmiah Didaktika, 18(2).

Rumelt, R. P. (2011). Good Strategy/ Bad Strategy The Difference Why It Matters. London : Profile Books.
Sadat, M Andi. 2009. Brand Belief: Strategi Membangun Merek Berbasis Keyaninan. Jakarta: Salemba Empat.

Schein, E. H. (2008). Organizational Culture and Leadership. San Fransisco: Jossey-Bass.

Sholihah, T. (2018). Strategi Manajemen Humas Dalam Menciptakan School Branding Pada Sekolah Islam Terpadu. Jurnal Manajemen Pendidikan Islam (JMPI), 3(2).

Tjiptpno, F. (2012). Pemasaran Strategik: Edisi 2.Yogyakarta: Penerbit Andi.

Tjiptono, F. (2005). Brand Management \& Strategy. Yogyakarta: Penerbit Andi. Undang-Undang Merek Tahun 2001 (situs Direktorat HAKI/ www.dgip.go.id)

Wijaya, D. (2008). Pemasaran jasa pendidikan sebagai upaya untuk meningkatkan daya saing sekolah. Jurnal Pendidikan Penabur, 11(7).

Wibowo, Ahmad Elly. 2018. Strategi Membangun Brand Image Dalam Meningkatakan Daya Saing Lembaga Pendidikan Man 2 Ponorogo. Tesis. Manajemen Pendidikan Islam IAIN Ponorogo. 